\title{
Effect of Leadership, Personality and Job Satisfaction On Job Performance of Diplomat
}

\author{
June Kuncoro Hadiningrat ${ }^{1}$, Muchlis R. Luddin ${ }^{2}$, Thomas Suyatno ${ }^{3}$ \\ ${ }^{1}$ Ministry of Foreign Affairs, the Republic of Indonesia \\ Jalan Pejambon no 6, Jakarta 10110, Indonesia \\ ${ }^{2}$ State University of Jakarta, Indonesia, Postgraduate Program in Management-HRM \\ Jalan Pemuda No 10, Jakarta 13220, Indonesia \\ mrantoni_luddin@yahoo.com \\ ${ }^{3}$ State University of Jakarta, Indonesia, Postgraduate Program in Management-HRM \\ Jalan Pemuda No 10, Jakarta 13220, Indonesia \\ thomas.suyatno@yahoo.com
}

\begin{abstract}
:
This research aims to study the effect of leadership, personality and job satisfaction on diplomat performance in the Ministry of Foreign Affairs of the Republic of Indonesia. The research methodology was a survey with path analysis applied in testing hypothesis. It was conducted among 158 diplomats selected by simple random sampling from 657 young diplomat population. Data analysis and interpretation indicate that (1) leadership has a positive direct effect on job performance of diplomat/diplomat performance, (2) personality has a positive direct effect on diplomat performance, (3) job satisfaction has a positive direct effect on diplomat performance, (4) leadership has a positive direct effect on job satisfaction, (5) personality has a positive direct effect on job satisfaction.
\end{abstract}

Keywords: leadership, personality, job satisfaction, diplomat performance

\section{Introduction}

1. Against the backdrop of fast-changing international sphere and mounting demand of domestic publics, diplomats of the Ministry of Foreign Affairs (MFA) are expected to perform their jobs well. In MFA, diplomats are key actors to achieve the goals of the organization that its main business is diplomacy or foreign relations. Diplomats work to exercise foreign policy and formulate foreign policy based on their observations on and interactions with foreign diplomats and other actors of international relations.

2. Bearing its constitutional role, Ministry of Foreign Affairs of the Republic of Indonesia (MFA-RI) is mandated to coordinate foreign relations of the Republic of Indonesia with other countries. According to Laws no 37/1999 on Foreign Relations (Undang Undang Hubungan Luar Negeri), article 31 and 32, Pejabat Dinas
Luar Negeri (Foreign Service Officers/FSO) are civil servants who have special training and education to work in the MFA-RI and its Indonesian Missions abroad. FSO are Diplomatic Officers or diplomats. To ensure the goals of MFA-RI are realized, diplomats should strive to perform their job as better as possible.

3. To gauge the diplomat performance, a simple preliminary research conducted on selected diplomats in the MFA-RI. The research shows that the diplomat performance has not yet reached the excellent level (with average score: 3,7 in the scale 1-5). Six elements of diplomat performance are relations building, negotiation ability, determinant attitude, crisis management ability, task accomplishment and foreign relations skills.

4. There are several factors affecting diplomat performance. Michael G. Aamodt (2010:250) 
points out eight factors affecting job performance: (1) ability, (2) supervision, (3) company policy, (4) economic factors, (5) motivation, (6) training, (7) physical environment and ; (8) co-workers. A previous research on MFA-RI employees by Tsani (2013) shows that there are the direct effect of competence, job placement and motivation on job performance of MFA-RI employees (diplomat and non-diplomat). The research assumes all the employees of MFA-RI as the identical group and does not differentiate between diplomat and non-diplomat employees who in fact have different job nature.

5. My research stands on the specific type of MFARI employees: diplomats, having the fact that the human resources (HR) aspects of diplomats -key employees in MFA-- are rarely addressed in the HR research. In addition, many research on diplomacy or international relations focus mainly --if not merely-- on the substance by which diplomat will use in practice like international law, conflicts, free trade, regionalism, climate change, war, diplomacy, negotiation and so on. In contrast, only limited research conducted on diplomats who carry out diplomatic works and utilize the above-mentioned substance. Research on management or personnel aspect of Foreign Service Office will therefore contribute to the shortage of human resources research focusing on MFA as well as the lack of research on diplomats in the study of diplomacy and international relations.

6. As far as my professional observation is concerned and my research stands, there are three main factors affecting job performance of diplomats: (1) leadership; (2) personality and (3) job satisfaction. The reasons are: First, as the diplomat is civil servant, then valuing leadership is a must. Second, personality; in line with the nature of the job, diplomat is a knowledge worker which is characterized by self-driven, result-oriented and highly-substantive work orientation. This requires personality quality. Three, Job satisfaction; like any other workers, job satisfaction of employee will effect on diplomat performance .

7. Different from Asamodt's factors affecting job performance, this research takes broader concept as follow: (1) leadership variable instead of "supervision", (2) personality variable instead of only "motivation"; and (3) job satisfaction variable rather than mere "economic factors" as well as "co-workers".

8. Based on this condition, the research seeks to understand the effect of leadership, personality and job satisfaction on the job performance. The research has hypothesis that there is direct effect of leadership, personality and job satisfaction on diplomat performance.

9. Job performance is defined as behaviors that is relevant the organization's goals and that can be measured in terms of the individual's contribution to organizational effectiveness, according to Ann Hanson and Borman (2014: 143). In relation to the diplomatic jobs, job performance can be measured by two perspectives: process performance and outcome performance, as Taris and Schauleffi state (2015: 21). Summing up some definition of job performance, the research applies seven dimension of job performance, using the definition of Viswesvaran and Ones (2005: 362) i.e. : (1) productivity or task performance; (2) interpersonal competence; (3) leadership; (4) effort; (5) job knowledge; (6) counterproductive behaviors; and (7) citizenship behaviors.

10. As diplomats work as team to represent the country, the leader or the chief of diplomats plays an important role in determining how the diplomacy is conducted and how diplomats carry out their duties. In the context of diplomat performance, leadership (or the superior of diplomats) will have effect on such performance. Leadership according to Gary Yukl is the process of influencing others (diplomats) to understand and agree about what needs to be done and how to do it. (2010:8). This research applies indicators of leadership as follows: (1) playing as a role model; (2) motivating staff; inspirational; (4) open for discussion; 
coaching staff, (6) decision making ; (7) giving feedback; (8) facilitating staff; (9) establishing relations with staff.

11. Referring to the definition coined by Duane P. Schultz and Sydney Ellen Schultz (2009:7), personality is defined as the unique aspect of individual affecting the character and behavior of diplomats responding different situations. This research adopts the 5 dimension of personality from Stephen Robbins and Timothy A. Judge (2014: 106) i.e. : (1) extraversion; (2) agreeableness; (3) conscientiousness; emotional stability; (5) openness to experience.

12. Job Satisfaction, according to Angelo Knicki and Robert Kreitner (2008: 162), is an affective or emotional response to one's job. To measure diplomats' job satisfaction, the research uses 5 dimension of job satisfaction of Jason A Colqutte, Jeffery A. LePine and Michael J. Wesson (2013, 100-101) as follows: (1) pay satisfaction; (2) promotion satisfaction; (3) supervision satisfaction; (4) co-worker satisfaction, (5) satisfaction with the work itself.

13. My research is conceived based on previous relevant researches. Regarding the influence of leadership on job performance, the previous research conducted by Teddy Chandra and Priyono on teachers of Junior High School in Surabaya shows that the leadership style, work environment as well as job satisfaction have impact on job performance (2016:131). On the impact of personality on job performance, a research conducted by Cheng-Liang Yang and Mark Hwang among employees of financial institutions in Taiwan shows all big five personality traits significantly influence on job performance. (2014:6). With regard to the influence of job satisfaction on job performance, the research of Ferit Olcer and Margareta Stela Florescu on employees of textile companies in Turkey unfolds the job satisfaction significantly affects job performance. (2015: 5).

14. In the meantime, the influence of independent variables (leadership and personality) on intermediate variables (job satisfaction) is shown in the following researches. Raimonda
Alonderiene and Modesta Mjauskaite's research on faculty members and supervisor of state universities in Lithuania reveals significant positive impact of leadership style on job satisfaction of faculty where servant leadership has the highest positive significant impact and the autocrat leadership has the lowest impact (2016: 40). The study of Qingguo Zhai, Mike Willis, Bob O'Shea, Yubo Zhai and Yuwen Yang conducted among urban workers in China found that extraversion was the strongest predictor of both job satisfaction and Subjective Well Being (SWB). This finding implies that extraversion could be more important that other factor in the Big Five in predicting job satisfaction and SWB. (2013:1099).

\section{Method}

15. The study was conducted in the Ministry of Foreign Affairs of the Republic of Indonesia in the headquarter in Jakarta and "its branches", the Indonesian representatives abroad: Indonesian Embassies/Consulate Generals/Consulates around the world where data is collected through questionnaire as the instrument of the research for diplomat performance (Y) variable, leadership (X1), personality (X2) and job satisfaction (X3). Instrument development for each variable is elaborated from conceptual definition, operational definition, instrument grid, instruments validity test and reliability calculation. Survey results and test will proceed by using path analysis using Microsoft Excel 2010 and SPSS v.22 software, which will then generate the level of influence of the independent variable to verity hypothesis. 


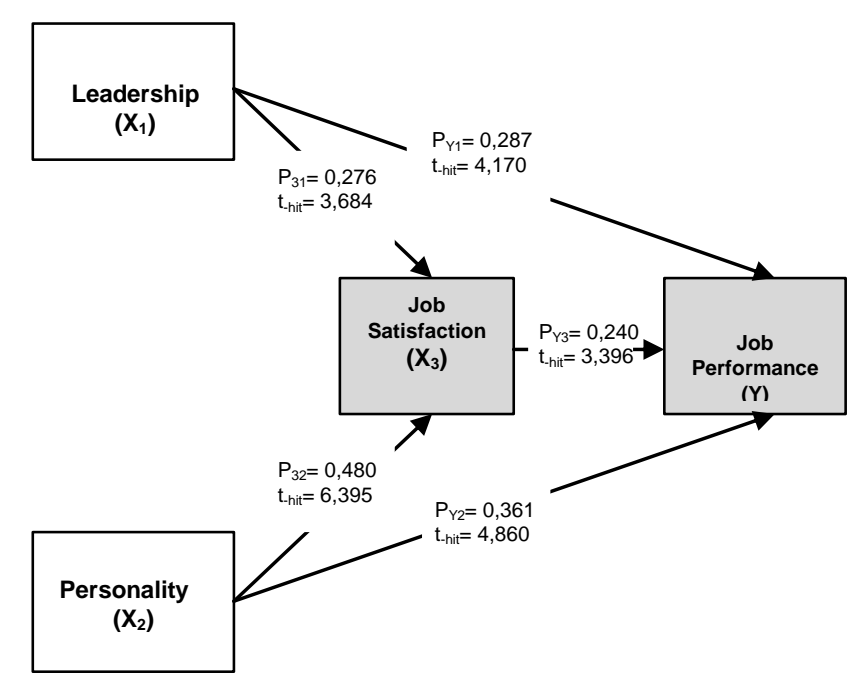

Figure 1. Summary of Hypothesis testing results equation model structure 1

Coefficients

Dependent Variable: Job Performance (Y)

Table 2. Summary of Hypothesis testing results equation model structure 2

Coefficients

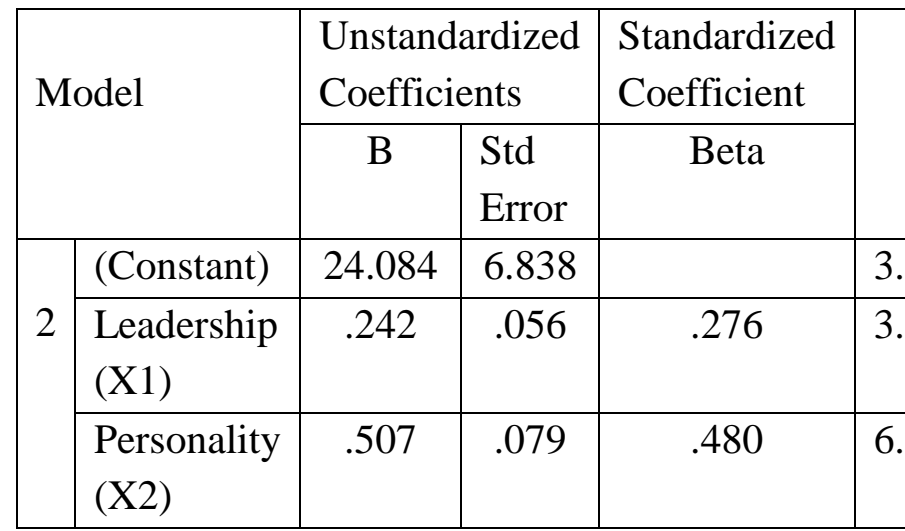

Dependent variable: Job Satisfaction (X3)

16. Based on the calculation and testing of the path coefficient, the relations among the variables can be described are as follows: (1) leadership (X1) has a direct positive influence on job performance (Y) obtained by coefficient path Py1 of 0,287 with t-count is 4,170, and t-table is $2,326(\mathrm{df}=156, \alpha=0,01)$, and as $\mathrm{t}$-count $>\mathrm{t}$-table, the $\mathrm{H} 0$ is rejected. Therefore, the result of this hypothesis testing is that there are a direct positive influence of leadership on job performance; (2) personality (X2) has a direct positive influence on job performance (Y) obtained by coefficient path Py1 of 0,361 with tcount is 4,860 , and t-table is 2,326 $(\mathrm{df}=156$, $\alpha=0,01$ ), and as $\mathrm{t}$-count $>\mathrm{t}$-table, the $\mathrm{HO}$ is rejected. Therefore, the result of this hypothesis testing is that there are a direct positive influence of personality on job performance; (3) job satisfaction (X3) has a direct positive influence on job performance $(\mathrm{Y})$ obtained by coefficient path Py1 of 0,240 with t-count is 3,396, and ttable is 2,326 $(\mathrm{df}=156, \alpha=0,01)$, and as $\mathrm{t}$-count $>\mathrm{t}$-table, the $\mathrm{H} 0$ is rejected. Therefore, the result of this hypothesis testing is that there are a direct positive influence of job satisfaction on job performance; (4) leadership (X1) has a direct positive influence on job satisfaction (X3) obtained by coefficient path Py1 of 0,276 with tcount is 3,684 , and t-table is 2,326 $(\mathrm{df}=156$, $\alpha=0,01)$, and as $\mathrm{t}$-count $>\mathrm{t}$-table, the $\mathrm{H} 0$ is rejected. Therefore, the result of this hypothesis testing is that there are a direct positive influence

\begin{tabular}{|c|c|c|c|c|c|}
\hline \multirow[t]{3}{*}{ Model } & \multicolumn{2}{|c|}{$\begin{array}{l}\text { Unstandardi } \\
\text { zed } \\
\text { Coefficients }\end{array}$} & $\begin{array}{l}\text { Stan } \\
\text { dard } \\
\text { ized }\end{array}$ & \multirow[t]{3}{*}{$\mathrm{T}$} & \multirow[t]{3}{*}{ Sig } \\
\hline & & & $\begin{array}{l}\text { ffici } \\
\text { ent }\end{array}$ & & \\
\hline & B & $\begin{array}{l}\text { Std } \\
\text { Error }\end{array}$ & $\begin{array}{c}\text { Bet } \\
\mathrm{a}\end{array}$ & & \\
\hline $\begin{array}{l}.0 \text { (edonstant) } \\
.000\end{array}$ & $\begin{array}{c}49.0 \\
77\end{array}$ & $\begin{array}{c}4.94 \\
6\end{array}$ & & $\begin{array}{l}9.9 \\
22\end{array}$ & $\begin{array}{c}.00 \\
0\end{array}$ \\
\hline $\begin{array}{l}\text { Leadership } \\
.9 Q^{\prime}(9)\end{array}$ & .199 & .048 & .287 & $\begin{array}{l}4.1 \\
70\end{array}$ & $\begin{array}{c}.00 \\
0\end{array}$ \\
\hline \begin{tabular}{|l} 
Personality \\
$(\mathrm{X} 2)$
\end{tabular} & .301 & .052 & .361 & $\begin{array}{l}4.8 \\
60\end{array}$ & $\begin{array}{c}.00 \\
0\end{array}$ \\
\hline \begin{tabular}{|l|} 
Job \\
Satisfaction \\
(X3)
\end{tabular} & .190 & .056 & .240 & $\begin{array}{l}33 . \\
396\end{array}$ & $\begin{array}{c}.00 \\
1\end{array}$ \\
\hline
\end{tabular}

of leadership on job satisfaction; (5) personality (X2) has a direct positive influence on job satisfaction (X3) obtained by coefficient path Py1 of 0,480 with t-count is 6,395, and t-table is 2,326 $(\mathrm{df}=156, \alpha=0,01)$, and as $\mathrm{t}$-count $>\mathrm{t}$-table, the $\mathrm{H} 0$ is rejected. Therefore, the result of this hypothesis testing is that there is a direct positive influence of personality on job satisfaction.

\section{Discussion}

17. Based on the statistical testing, the research suggests the influence of leadership on job performance of diplomats. In practice, superiors 
in the MFA-RI thus should develop the effective leadership skills to influence their staff in carrying out diplomacy works. As this research uses dimensions of leadership like being a role model, motivating staff, being inspirational, open for discussion, coaching staff, decision making, giving feedback, facilitating staff and establishing relations with staff, superiors/supervisors should thus enhance such dimension. As Gary Yukl said that leadership is the process of influencing others, the dimensions of leadership should be developed to improve the skill of influencing subordinate in order to accomplish shared objectives of organization. Following Fred C. Lunenburg and Allan C. Ornstein's theory (2008: 148), the behaviors of leader significantly influence the behaviors of subordinates, therefore the good behavior/performance of leaders will influence the behaviors of subordinates to accomplish the organization's objectives.

18. The findings of the research show that the performance of diplomats is influenced by their personality. Personality traits affect the behavior and the performance of diplomats in the context of the organization. Hence, having personality traits like extraversion, agreeableness, conscientiousness, emotional stability and openness to experience, diplomats are likely to perform better in their diplomatic tasks. The results of the research support the previous research and study on the influence of personality on job performance such as those of Muhammad Bhatti, Mohammed Batour and Ahmed Ismail (2014: 73-96) and Ioannis Nikolau (2003: 69-648).

19. As job satisfaction is frequently mentioned as a key factor to the job performance, this research similarly proves that job satisfaction of diplomat influences their job performance. This is further explained by Don Wicker (2011: 3) : To the worker, job satisfaction brings a pleasurable emotional state that often leads to a positive work attitude and improved performance. A satisfied worker is more likely to be creative, flexible, innovative and loyal.
20. Being satisfied, diplomats will show creativity, flexibility, innovation and loyalty in daily works. The organization should create and maintain situation that contribute to the feeling of satisfaction among diplomats. As Jason A Colqutte, Jeffery A. LePine and Michael J. Wesson indicate that pay satisfaction, promotion satisfaction, supervision satisfaction, co-worker satisfaction, and satisfaction with the work itself are factors affecting job satisfaction, in the context of MFA-RI, it needs further to research which factor most significantly affecting job performance of diplomats so the relevant policy could be passed.

21. Related to the job satisfaction of diplomats, the empirical findings of the research show that leadership determines job satisfaction of diplomats, beside leadership directly affects job performance of diplomats. Effective leadership proves to create the job satisfaction of diplomats. This condition, according to Dimitros Belias and Athanasios Koustellios, can only work in flexible organizations with participative management type with emphasis in communication and employees rewards. (2015: 104).

22. While job satisfaction is often determined by external factors of employees, internal factors of individuals in fact also play an important role in determining job satisfaction. This research reveals that personality of diplomat such as extraversion, agreeableness, conscientiousness, emotional stability and openness to experience has an direct positive impact on job satisfaction of diplomat. The previous study conducted by Qingguo Zhai et al reveals extraversion is the most influential factor (2013: 1099) to job satisfaction while the research of Christopher A. Cooper, Dale Carpenter, Audrey Reiner and David M. McCord found that extraversion and agreeableness is most influential to job satisfaction.(2014: 155-162)

\section{Conclusion}

23. Based on the above findings, the research concludes that (1) leadership has a direct 
positive effect on the performance of diplomats in the Ministry of Foreign Affairs of the Republic of Indonesia (MFA-RI). These findings demonstrate that effective leadership like giving examples, inspirational, establishing relations with staff has positive impact on improving and encouraging diplomat performance; personality has a direct positive effect on job performance of diplomats of MFA-RI. The results signify that positive personality like extraversion, agreeableness, conscientiousness, emotional stability and openness to experience contributes to the job performance of diplomats; (3) job satisfaction has a direct positive effect on performance of diplomats of MFA-RI. The findings show job satisfaction such as pay satisfaction, promotion satisfaction, supervision satisfaction, co-worker satisfaction, and satisfaction with the work itself encourages job performance of diplomats of MFA-RI; (4) leadership has a direct positive impact on job satisfaction of diplomats; The findings show the effective leadership like playing as a role model, motivating staff, or establishing relations with staff will cause the increase of job satisfaction of diplomats; (5) personality has a direct positive impact on job satisfaction of diplomats. The results show that positive personality traits like extraversion, agreeableness, conscientiousness, emotional stability and openness to experience likely contribute to the increasing job satisfaction.

\section{Reference}

[1] Aamodt, Michael G. (2010), Industrial/Organizational Psychology: An Applied Approach. Belmont: Cengage Learning.

[2] Alonderiene, Raimonda dan Modesta Majauskaite (2016), "Leadership Style and Job Satisfaction in Higher Education Institutions", International Journal of Educational Management, Vol. 30 No. 1.

[3] Ann Hanson, Mary dan Walter C. Borman (2014), Citizenship Performance: An Integrative Review and Motivational Analysis, eds.Winston Bennett, Charles E.
Lance, dan David J. Woehr, New York: Psychology Press.

[4] Bhatti, Muhammad Awais, Mohamed Mohamed Battour, Ahmed Rageh Ismail, dan Veera Pandiyan Sundram, "Effects of Personality Traits (Big Five) on Expatriates Adjustment and Job Performance", Equality, Diversity and Inclusion: An International Journal, Vol. 33 Iss 1, 2014

[5] Belias, Dimitrios and Athanasios Koustelios (2015), "Leadership Style, Job Satisfaction and Organizational Culture in the Greek Banking Organization", Journal of Management Research, Vol. 15, No. 2.

[6] Chandra,Teddy dan Priyono (2016), "The Influence of Leadership Styles, Work Environment and Job Satisfaction of Employee Performance: Studies in the School of SMPN 10 Surabaya", International Education Studies; Vol. 9, No. 1.

[7] Colquitt, Jason A., Jeffery A. LePine dan Michael J. Wesson (2013), Organizational Behavior: Improving Performance and Commitment in the Workplace, New York: McGraw-Hill Companies, Inc.

[8] Cooper, Christopher A., Dale Carpenter, Audrey Reiner and David M. McCord (2014), "Personality and Job Satisfaction: Evidence from a Sample of Street-Level Bureucrats", International Journal of Public Administration, Vol. 7.

[9] Kinicki, Angelo dan Robert Kreitner (2018), Organizational Behavior: Key Concepts, Skills \& Best Practice, New York: McGrawHill Companies, Inc.

[10] Lunenburg, Fred C. dan Allan C. Ornstein (2008), Education Administration: Concepts \& Practices, Belmont: Thomson Higher Education.

[11] Nikolaou, Ioannis (203), "Fitting the person to the organization: examining the personality-job performance relationship from a new persepective", Journal of Managerial Psychology, Vol. 18, Iss 7. 
[12] Ölçer, Ferit dan Margareta Stela Florescu (2015), "Mediating Effect of Job Satisfaction in the Relationship Between Psychological Empowerment and Job Performance", Journal of Business Excellence and Management, Vol. 5, Issue 1.

[13] Robbins, Stephen P. dan Timothy A. Judge (2014), Essential of Organizational Behavior, New Jersey: Pearson Education, Inc.

[14] Schultz, Duane P. dan Sydney Ellen Schultz (2009), Theories of Personality, Belmont: Wadsworth.

[15] Taris, Toon W. dan Wilmar B. Schaufeli (2015), Individual Well-Being and Performance at Work: A Conceptual and Theoretical Overview, eds. Marc Van Veldhoven dan Riccardo Peccei, New York: Psychology Press.

[16] Tsani, Ahrul (2013), "Pengaruh Kompetensi, Penempatan Kerja dan Motivasi terhadap Kinerja Pegawai Sekretariat Jenderal Kementerian Luar Negeri", Jurnal MIX, Volume III, No.1.

[17] Viswesvaran, Chockalingam dan Deniz S. Ones (2005), Job Performance: Assessment Issues in Personnel Selection, eds. Arne Evers, Neil Anderson, dan Olga SmitVoskuijl, Malden: Blackwell Publishing Ltd.

[18] Wicker, Don (2011), Job Satisfaction: Fact or Fiction, Bloomington: Author House.

[19] Yang, Cheng-Liang dan Mark Hwang, "Personality Traits and Simultaneous
Reciprocal Influences between Job Performance and Job Satisfaction", Chinese Management Studies, Vol. 8, No. 1, 2014.

[20] Yukl, Gary (2010), Leadership In Organization, New Jersey: Pearson Education, Inc.

[21] Zhai, Qingguo, Mike Willis, Bob O'Shea, Yubo Zhai, dan Yuwen Yang (2013), "Big Five Personality Traits, Job Satisfaction and Subjective Wellbeing in China", International Journal of Psychology, Vol. 48, No. 6.

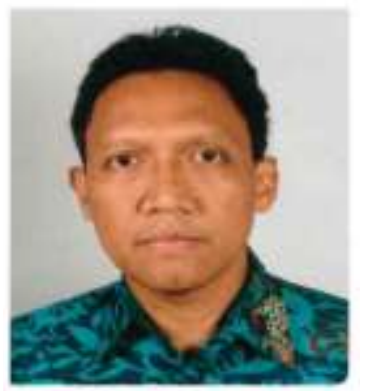

June

Kuncoro

Hadiningrat received Bachelor Degree (Drs.) in Journalism/Mass Communication from University of Indonesia in 1993 and hold two master degrees, MSc. in Communication Science from University of Leeds, UK in 1995 by British Chevening Award Scholarship and MA in International Relations from University of Indonesia in 1999 under the scholarship of the Ministry of Foreign Affairs of the Republic of Indonesia. This article is based on the research of his doctoral degree in Human Resources Management in State University of Jakarta (UNJ) 2012-2017. He has been working in the Ministry of Foreign Affairs of the Republic of Indonesia since 1997 and has served in Indonesian Embassies in Kuala Lumpur (20002004), Rome (2008-2012) and the Hague (20152018). He taught the subject of International Communication and Marketing Communication in the University of Indonesia 1993-2000. 